\title{
Blood-Vessel Mimicking Structures by Stereolithographic Fabrication of Small Porous Tubes Using Cytocompatible Polyacrylate Elastomers, Biofunctionalization and Endothelialization
}

\author{
Birgit Huber ${ }^{1}$, Sascha Engelhardt ${ }^{2}$, Wolfdietrich Meyer ${ }^{3}$, Hartmut Krüger $^{3}$, Annika Wenz ${ }^{1}$, \\ Veronika Schönhaar ${ }^{4}$, Günter E. M. Tovar ${ }^{1,4}$, Petra J. Kluger ${ }^{4,5}$ and Kirsten Borchers ${ }^{1,4, *}$ \\ 1 Institute of Interfacial Process Engineering and Plasma Technology IGVP, University of Stuttgart, \\ Stuttgart 70569, Germany; biggihuber@gmx.de (B.H.); annika.wenz@igvp.uni-stuttgart.de (A.W.); \\ guenter.tovar@igvp.uni-stuttgart.de (G.E.M.T.) \\ 2 Rheinisch-Westfälische Technische Hochschule Aachen, RWTH Aachen, Aachen 52074, Germany; \\ sascha.engelhardt@rwth-aachen.de \\ 3 Fraunhofer Institute for Applied Polymer Research IAP, Potsdam 14476, Germany; \\ wolfdietrich.meyer@iap.fraunhofer.de (W.M.); hartmut.krueger@iap.fraunhofer.de (H.K.) \\ 4 Fraunhofer Institute for Interfacial Engineering and Biotechnology IGB, Stuttgart 70569, Germany; \\ veronika.schoenhaar@igb.fraunhofer.de (V.S.); petra.kluger@igb.fraunhofer.de (P.J.K.) \\ 5 Process Analysis \& Technology (PA\&T), Reutlingen University, Reutlingen 72762, Germany \\ * Correspondence: kirsten.borchers@igb.fraunhofer.de; Tel.: +49-711-970-4121; Fax: +49-711-970-4200 \\ Academic Editor: Ali Khademhosseini \\ Received: 26 January 2016; Accepted: 8 April 2016; Published: 20 April 2016
}

\begin{abstract}
Blood vessel reconstruction is still an elusive goal for the development of in vitro models as well as artificial vascular grafts. In this study, we used a novel photo-curable cytocompatible polyacrylate material (PA) for freeform generation of synthetic vessels. We applied stereolithography for the fabrication of arbitrary 3D tubular structures with total dimensions in the centimeter range, $300 \mu \mathrm{m}$ wall thickness, inner diameters of 1 to $2 \mathrm{~mm}$ and defined pores with a constant diameter of approximately $100 \mu \mathrm{m}$ or $200 \mu \mathrm{m}$. We established a rinsing protocol to remove remaining cytotoxic substances from the photo-cured PA and applied thio-modified heparin and RGDC-peptides to functionalize the PA surface for enhanced endothelial cell adhesion. A rotating seeding procedure was introduced to ensure homogenous endothelial monolayer formation at the inner luminal tube wall. We showed that endothelial cells stayed viable and adherent and aligned along the medium flow under fluid-flow conditions comparable to native capillaries. The combined technology approach comprising of freeform additive manufacturing (AM), biomimetic design, cytocompatible materials which are applicable to AM, and biofunctionalization of AM constructs has been introduced as BioRap $^{\circledR}$ technology by the authors.
\end{abstract}

Keywords: stereolithography; artificial blood vessel; small branched and porous tubes; biofunctionalization; thio-modified heparin; endothelialization

\section{Introduction}

New materials for additive manufacturing (AM) methods are gaining more and more interest for applications in medical engineering and medicine. Computer-based AM techniques can directly transform digital data into physical objects through layer-by-layer material deposition or layerwise material solidification. One particular focus is on photo-curable polymers for laser-based additive assembly of complex or individualized three-dimensional (3D) structures. In recent years, AM has already been utilized for assembling patient specific models from 3D images acquired by computer 
tomography or surface scanning enabling surgeons to plan complex interventions, to pre-adjust implants or to fabricate individualized surgical guides [1,2]. Future applications will increasingly comprise the fabrication of biocompatible and biofunctional scaffolds for the development of tissue models and implants with an individual shape [3]. Blood vessel reconstruction is of particular interest for both the development of in vitro models and artificial vascular prostheses. While the material specification list for blood vessel replacement in vivo is long and extremely challenging [4], the basic requirements for tubular supply systems for 3D tissue engineering are permeability and cytocompatibility. The inability to provide a sufficient and functional blood vessel system today is one of the main limitations in obtaining thick viable tissue models with the potential of mimicking the complex functions of native tissue [5]. With regard to the supply of several cubic millimeters of cells in a 3D matrix, tubular systems with single inlet, multiple branches, single outlet, and adjustable geometry are required. Endothelial cell adhesion and monolayer formation at the inner tube surface are additional prerequisites for simulating the controlled exchange of substances across the endothelial barrier. Fabrication of porous tubes has been realized earlier, e.g., by freeze-drying of biopolymers [6] or by electro-spinning of a broad range of materials [7,8]. Extrusion of bio-based materials and blends using coaxial nozzles also resulted in hollow fibers, which can eventually be perfused $[9,10]$. As drawback, such methods cannot produce branched structures. With shaping techniques, such as nanoimprint lithography or microcontact printing, more complex and branched microfluidic channels have been created [11-13]. However, the micro-channels thus produced are limited in application in engineering larger tissues $[11,14]$. The newly emerging AM techniques are now increasingly implemented to fabricate perfusable structures in a broad range of scales. We have recently reviewed current approaches to (bio-)printing of artificial blood vessels [15]. The most straightforward approach to perfusable tissue supply systems is the generation of a network of interconnected channels within the tissue matrix [16-18]. This has been achieved by extrusion-based deposition of branched networks of sacrificial materials such as carbohydrates, which were removed after a crosslinked cell-laden matrix had been added. Alternatively, hydrogel-based tubular structures with very high aspect ratios have, e.g., been fabricated by assembly of microspheres of crosslinked alginate, which formed by ejection of alginate droplets into a solution of $\mathrm{CaCl}_{2}[19,20]$. Complex geometries such as that of branched blood vessels are now increasingly implemented in various scales by the newly emerging AM techniques. One major challenge is to support free-standing structures during buildup. Branched geometries have been assembled by the combined deposition of building materials and support materials [21,22]. The dimensions of such model structures are still in the centimeter range. Laser-based methods, e.g., stereolithography, two-photon-polymerization or digital light processing, induce solidifying of a photo-curable resin by layerwise selective crosslinking, and thus avoid the need of additional support. Such techniques have also been used to generate very tiny branched structures [23] or microstructured vessel walls [24] using acrylated polymers. Thus, obviously, the use of AM techniques has brought us closer towards the construction of perfusable tissue models and provides an alternative to the use of decellularized biological donor scaffolds. Consequently, there is a comprehensive need for new biomaterials capable of being applied in AM processes.

We have previously developed new material formulations which can be used for AM applications and tissue culture due to photo-reactivity, cytocompatibility, adjustable viscosity and the ability to tune the elastic properties of the cured materials $[23,25,26]$. However, synthetic materials that have been primarily adjusted to be processed in AM techniques are not necessarily cytocompatible or support cell adhesion. In this study, we suggest using thio-modified heparin and cysteine-coupled arginine-glycine-aspartic acid (RGDC) peptides for biofunctionalization of polyacrylate surfaces. We introduce the stereolithography-based method to fabricate porous tubes and branched tubular systems with $17 \mathrm{~mm}$ total length, $12 \mathrm{~mm}$ total width, and defined $100 \mu \mathrm{m}$ pores from a novel acrylate based resin. A rinsing protocol was established to achieve cytocompatibility of the photo-cured material. Further, a seeding procedure with endothelial cells in a fluid-flow bioreactor with shear rates 
comparable to native capillaries was established for endothelial monolayer formation on the tube's luminal surface in vitro.

\section{Results}

\subsection{Post-Curing Treatments of UV-Cured PA}

We developed an acrylate resin that is applicable in printing processes as well as for laser-based curing by stereolithography. We investigated UV-cured films in terms of post-curing treatments. Post-curing comprised a rinsing protocol in ethanol $(\mathrm{EtOH}, 70 \%)$ to achieve PA cytocompatibility, PA immersion within physiological buffer solution (PBS), and gamma $(\gamma)$-sterilization. Cytocompatibility testing was performed in a general way using fibroblast cells as recommended in DIN ISO 10993-5 [27]. Compatibility with endothelial cells was further confirmed by the seeding experiments of the material described in Section 2.4.

Rinsing in $\mathrm{EtOH}(70 \%)$ for five days increased the cytocompatibility of UV-cured PA from $31 \% \pm 6.7 \%$ fibroblast viability on day one to $97 \% \pm 7.2 \%$ on day five in relation to standard tissue culture petri dish (TCPD) substrates (Figure 1). Subsequent removal of EtOH by evacuation was crucial to achieve the cytocompatibility.

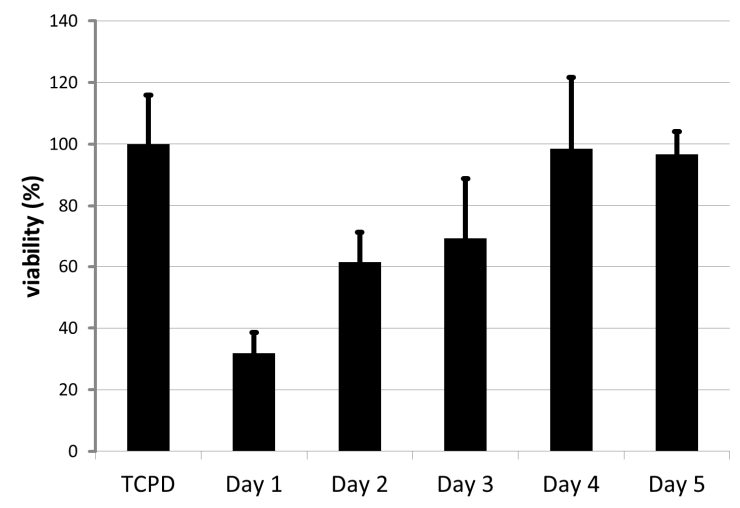

Figure 1. Viability of human fibroblasts cultured with material extracts for $24 \mathrm{~h}$.

Cured polyacrylate (PA) was rinsed in $\mathrm{EtOH}(70 \%)$ for one to five days. Extracts from every material sample were tested according to DIN ISO 10993-5. The cell viability of PA was comparable to those cultured on tissue culture petri dishes (TCPD) after washing for four and five days.

A slight mass loss of $0.48 \% \pm 0.22 \%$ was measured after the washing procedure of the PA material indicated the removal of soluble compounds. The immersion of UV-cured PA in EtOH (70\%) hardly changed the Young's modulus of the dried material ( 18 MPa), while tensile strength dropped from $2.9 \pm 0.4 \mathrm{MPa}$ to $1.7 \pm 0.1 \mathrm{MPa}$ (Table 1). Immersion of UV-cured PA in PBS resulted in an increase of the Young's modulus and tensile strength from 18.8 $\pm 1.7 \mathrm{MPa}$ to $24.6 \pm 2.3 \mathrm{MPa}$ and from $2.9 \pm 0.4 \mathrm{MPa}$ to $3.5 \pm 0.1 \mathrm{MPa}$, respectively. After $\gamma$-sterilization, the modulus and tensile strength rose from $18.8 \pm 1.7 \mathrm{MPa}$ to $21.3 \pm 2.1 \mathrm{MPa}$ and from $2.9 \pm 0.4 \mathrm{MPa}$ to $3.2 \pm 0.5 \mathrm{MPa}$, respectively.

Table 1. Young's modulus and tensile strength of PA after four min of UV-curing, before and after additional rinsing for five days in $\mathrm{EtOH}(70 \%)$, and after additional $24 \mathrm{~h}$ immersion in physiological buffer or after additional gamma sterilization.

\begin{tabular}{ccc}
\hline PA Material & Young's Modulus (MPa) & Tensile Strength (MPa) \\
\hline UV (4 min) & $18.8 \pm 1.7$ & $2.9 \pm 0.4$ \\
UV (4min) + EtOH (70\%) treatment and dried in vacuum & $18.3 \pm 0.4$ & $1.7 \pm 0.1$ \\
UV (4 min) $+\gamma$-sterilization & $21.3 \pm 2.1$ & $3.2 \pm 0.5$ \\
UV (4 min) + PBS buffer & $24.6 \pm 2.3$ & $3.5 \pm 0.1$ \\
\hline
\end{tabular}




\subsection{Production of Tubular Structures by Stereolithography}

For the fabrication of branched and porous tubular structures a protocol for stereolithographic (SLA) curing of the resin was developed and the curing depth for the SLA process using the new PA resin was minimized. The curing depth $C_{D}$ was determined at a fixed mean laser power of $25.4 \mathrm{~mW}$. Variation of scan velocities between $50 \mathrm{~mm} \mathrm{~s}^{-1}$ to $410 \mathrm{~mm} \mathrm{~s}^{-1}$ resulted in exposure between $160 \mathrm{~mJ} \mathrm{~cm}^{-2}$ and $1307 \mathrm{~mJ} \mathrm{~cm}^{-2}$. When plotted in semi-logarithmic scale, the working curve followed the expected linear relationship (Figure 2). The minimum curing depth was approximately $10 \mu \mathrm{m}$ and increased up to $30 \mu \mathrm{m}$ for higher exposures. For small exposures, i.e., high scanning speeds, the experimental data slightly deviated from the linear correlation. Based on these results, the layer separation distance was set to $20 \mu \mathrm{m}$ to $30 \mu \mathrm{m}$ for the generation of 3D tubular structures. The SLA process was then used to assemble linear tubular structures, branched tubular structures, and tubular structures with defined pores (Figure 3). The total length of the linear tubes was $30 \mathrm{~mm}$, the inner diameter was $2 \mathrm{~mm}$ and the wall thickness was $200 \mu \mathrm{m}$. The pore diameter was $100 \mu \mathrm{m}$ over the full wall thickness. The length of the branched tubular structures from inlet to outlet was $17 \mathrm{~mm}$, the inner diameter was $1 \mathrm{~mm}$ and the wall thickness was $300 \mu \mathrm{m}$.

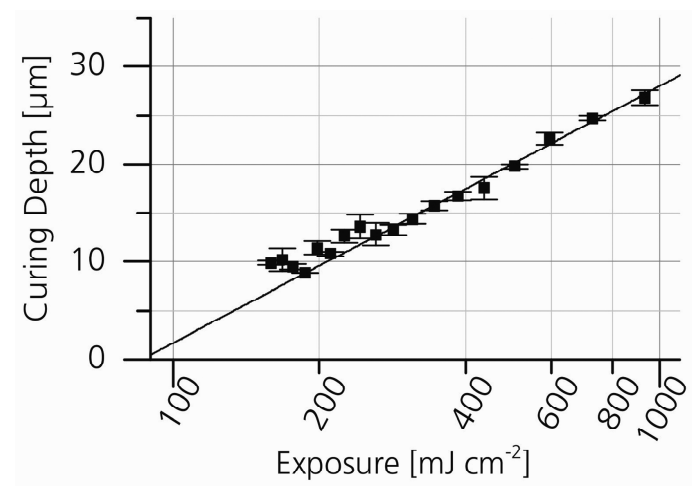

Figure 2. Curing depth plotted as a function of exposure. The smallest achievable curing depth for the PA resin with the used setup was approximately $10 \mu \mathrm{m}$.
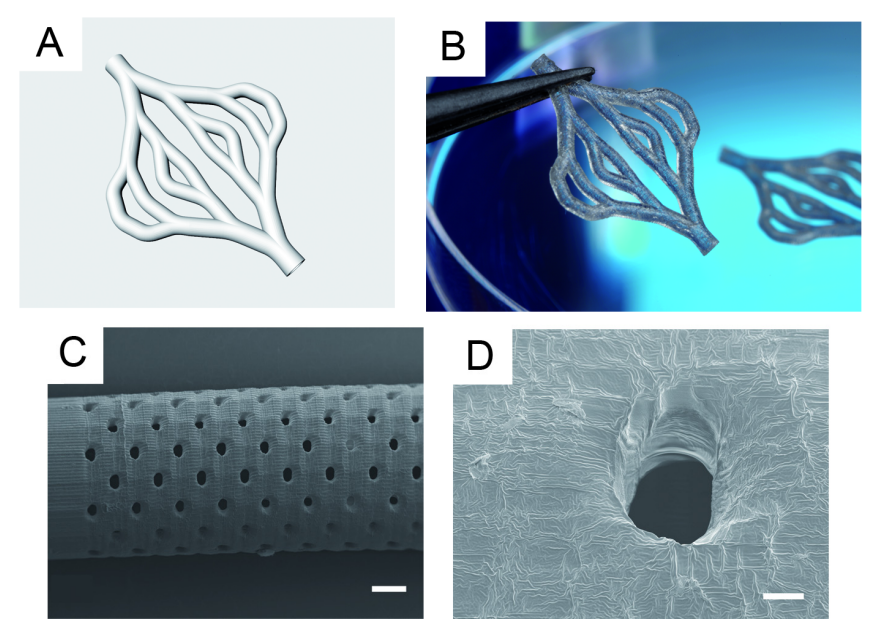

Figure 3. SLA-produced porous and branched tubular structures: (A) 3D model of a branched tubular structure, kindly provided by the University of Loughborough. (B) SLA fabricated tubular structure according to the design shown in (A). The inner diameter of the smallest branches is $1 \mathrm{~mm}$ the wall thickness is $300 \mu \mathrm{m}$. The complete construct is $12 \mathrm{~mm}$ wide and $17 \mathrm{~mm}$ high. (C) SEM image of a linear porous tube (scale bar: $400 \mu \mathrm{m}$ ). The inner diameter of the tube is $2 \mathrm{~mm}$, the wall thickness is $200 \mu \mathrm{m}$ and the total length is $30 \mathrm{~mm}$. (D) Magnification of a single pore (scale bar: $40 \mu \mathrm{m}$ ). The diameter is approximately $100 \mu \mathrm{m}$ spanning the entire wall crossection of $200 \mu \mathrm{m}$. 


\subsection{PA Surface Functionalization with Thio-Modified Heparin and RGDC-Peptides}

With regard to providing model systems for small blood vessels we considered the integration of an endothelial monolayer. Thio-modified heparin and cysteine-coupled RGD were applied in order to equip the PA surfaces with cell recognition sites to enable the adhesion endothelial cells. Thio-modified heparin was synthesized by EDC mediated reaction of heparin with the dihydrazide linker DTPH and subsequent DTT mediated dissociation of the S-S bond. The successful derivatization of heparin was verified by ${ }^{1} \mathrm{H}-\mathrm{NMR}\left(\mathrm{D}_{2} \mathrm{O}\right.$ and $\left.500 \mathrm{MHz}\right)$. Figure 4 shows spectra of unmodified heparin and a thio-modified derivative. The resonances detected for thio-modified heparin at $\delta=2.65 \mathrm{ppm}$ and $\delta=2.85 \mathrm{ppm}$ were assigned to the insertion of two methylene groups by DTPH conjugation.

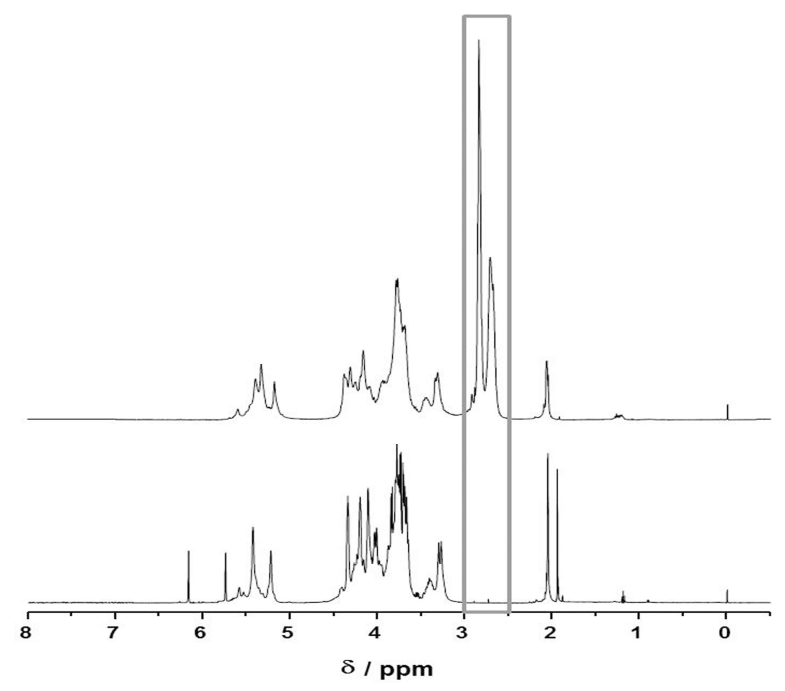

Figure 4. 1H-NMR spectra of heparin (bottom) and thio-modified heparin (top). Signals at the chemical shift of $\delta=2.65 \mathrm{ppm}$ and the chemical shift of $\delta=2.85 \mathrm{ppm}$ correspond to methylen protons of the thio-functional linker.

X-ray photon spectroscopy (XPS) was applied in order to investigate the chemical surface composition of pristine PA substrates and of PA substrates after incubation with aqueous solutions of the biomolecule derivatives. The results are summarized in Table 2. Sulfur (S) and nitrogen (N) signals were taken as proof for the presence of thio-modified heparin or RGDC peptides at the polymer surface because such elements were not present at pristine PA surfaces. Additionally, decreases of the atomic percentage of aliphatic carbon $\left(\mathrm{C}_{\mathrm{ali}}\right)$ indicated the formation of a surface coating, because aliphatic carbon was present mainly in the bulk polymer but only at low ratios in heparin and RGDC. The unchanged percentage of $C_{\text {ali }}$ in untreated PA and PA treated with RGDC together with the absence of $\mathrm{S}$ or $\mathrm{N}$ indicated that the amount of peptides present at the surface was below the detection limit of XPS or that direct coupling of RGDC to the PA surface was not successful at all.

In contrast, at PA surfaces treated with thio-modified heparin or thio-modified heparin and RGDC, $\mathrm{S}$ and $\mathrm{N}$ were clearly detected. The relative amounts of $\mathrm{S}$ detected after functionalization with thio-heparin and functionalization with thio-modified heparin/RGDC was 0.3 at. $\%$ and 0.4 at. $\%$, respectively, not indicating any significant changes of the $S$ content upon RGDC coupling. The relative amount of $\mathrm{N}$ increased to $0.6 \pm 0.1$ at.\% upon functionalization with thio-modified heparin and to $1.1 \pm 0.1$ at. $\%$ upon RGDC coupling. The approximated $\mathrm{C}_{\mathrm{ali}}: \mathrm{N}: \mathrm{S}$ ratio of double disaccharide units of heparin is in the range of 0:2:(1-6) depending on the degree of sulfation and thio-modification. For the RGDC peptide the ratio is 2:8:1, thus the prominent increase of the $\mathrm{N}$ signal compared to the smaller increase of the $S$ signal indicated the coupling of RGDC peptides to the thio-heparin coated surfaces. 
Table 2. Results of XPS analysis of PA surfaces without treatment, after immersion with RGDC solution, solution of thio-modified heparin, or both biomolecules in sequence: $168.2 \mathrm{eV}$ to $168.4 \mathrm{eV}$ binding energy of sulfate-sulfur, $163.4 \mathrm{eV}$ binding energy of sulfur from S-C bonds, $399.7 \mathrm{eV}$ to $401.4 \mathrm{eV}$ binding energies of nitrogen in amide bonds and amino functions, $284.6 \mathrm{eV}$ binding energy of aliphatic C-C bonds.

\begin{tabular}{ccccc}
\hline Title & Untreated PA & RGDC & Thio-Modified Heparin & Thio-Modified Heparin/RGD \\
\hline Mean average/at. $\%$ & & & & \\
\hline C1 $(284,6 \mathrm{eV})$ & 49.4 & 50.3 & 46.6 & 45.0 \\
S1 $(168.2 \mathrm{eV}$ to & 0.0 & 0.0 & 0.2 & 0.2 \\
168.4 eV) & 0.0 & 0.0 & 0.1 & 0.2 \\
S2 (163.4 eV) & 0.0 & 0.0 & 0.6 & 1.1 \\
N total & & & & 0.5 \\
\hline Standard deviation/at. $\%$ & 2.5 & 0.1 & 0.1 & 0.0 \\
\hline C1 $(284,6 \mathrm{eV})$ & 0.0 & 0.0 & 0.0 & 0.1 \\
S1 $(168.2 \mathrm{eV}$ to & 0.0 & 0.0 & 0.0 & 0.1 \\
168.4 eV) & 0.0 & 0.0 & 0.1 & \\
S2 $(163.4 \mathrm{eV})$ & & & \\
N total & & & & \\
\hline
\end{tabular}

\subsection{Endothelial Cell Culture on Planar and Tubular Substrates}

The adhesion and proliferation of human dermal microvascular endothelial cells (HDMEC) on planar material samples of pristine PA and functionalized PA were investigated after $24 \mathrm{~h}$ (Figure 5). On PA coated with thio-modified heparin and RGDC, a confluent cell monolayer formed comparable to that on TCPD. On non-functionalized PA and on surfaces that had been treated with the RGDC peptides or the thio-modified heparin separately, non-confluent cell colonies were found.
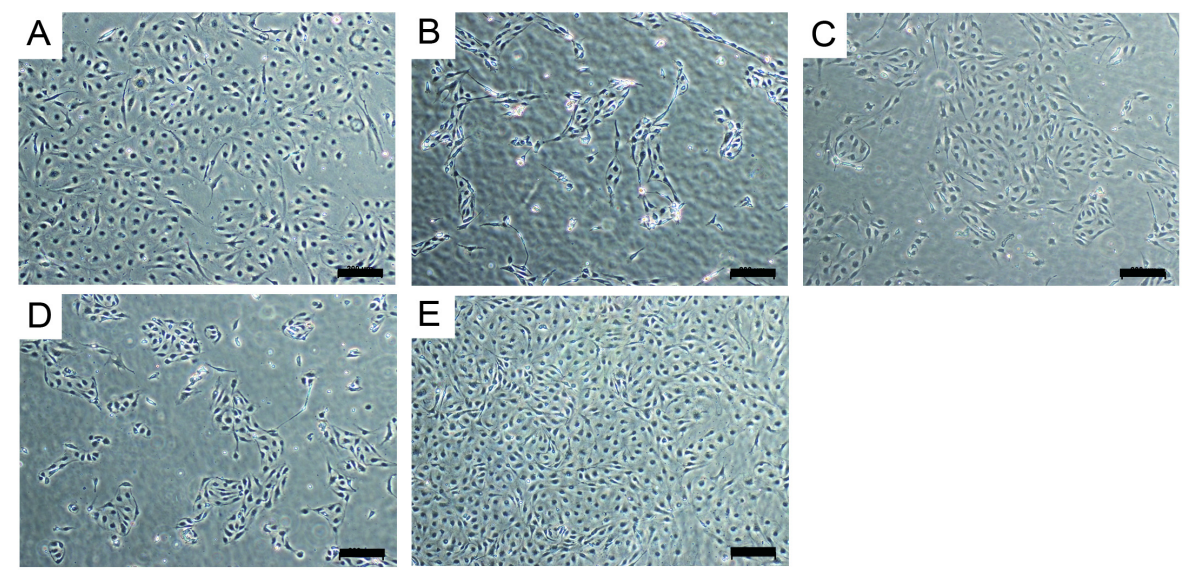

Figure 5. Light microscopic images of Human dermal microvascular endothelial cells (HDMECs) seeded on various surfaces for $24 \mathrm{~h}$ : (A) Tissue culture petri dish TCPD as control surface; (B) Untreated PA; (C) Polyacrylate (PA) functionalized with thio-modified heparin; (D) PA treated with cysteine-coupled arginine-glycine-aspartic acid (RGDC); and (E) PA functionalized with thio-modified heparin/RGDC (scale bar: $200 \mu \mathrm{m}$ ). Only few cells attached to the non-functionalized PA as well as on the PA treated with thio-modified heparin or RGDC. The functionalization with thio-modified heparin/RGDC resulted in a confluent cell monolayer comparable to the TCPD.

For seeding HDMECs to the luminal walls of PA tubes, static and rotating setups were compared. Static incubation of cell suspension within the tube lumen resulted in cell attachment exclusively at the tubes' bottom and thus in inhomogeneous cell layers. When the non-porous tube was rotated for $4 \mathrm{~h}$ during cell attachment homogenous endothelial cell adhesion to the complete inner tube wall was 
achieved. Cell attachment was generally lower on non-functionalized tubes than on biofunctionalized PA tubes (Figure 6). For porous tubes, the seeding procedure was modified. After $1 \mathrm{~h}$ rotation, cells were further allowed to proliferate for four days while cultured statically to compose a confluent monolayer in porous tubes. Assumingly, this was necessary because part of the cells were lost due to transiting the porous tube walls.
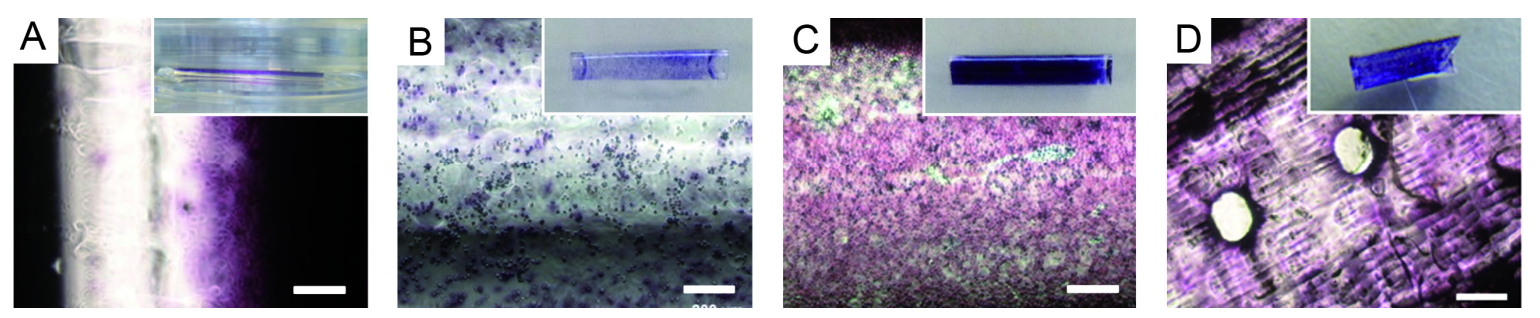

Figure 6. Endothelialization of tubular PA substrates. (A) static seeding led to non-confluent monolayers on one side of the tube; $(\mathbf{B})$ rotating seeding of non-functionalized PA tubes resulted in low cell attachment all over the tube; (C) rotating cell seeding of tubes functionalized with thio-modified heparin/RGDC resulted in confluent monolayers on the inner surface; and (D) for the seeding of porous materials, an improved protocol was used. Scale bar: $200 \mu \mathrm{m}$.

The effectiveness of cell seeding to the inner wall of polyacrylate tubes was compared applying the cell suspension in a static way or by rotating the tube at $0.5 \mathrm{rpm}$ for $4 \mathrm{~h}$ at $37^{\circ} \mathrm{C}$. Cell density and viability was detected by MTT for: (A-C) non-porous tubes; (D) porous tube with pore size of approximately $200 \mu \mathrm{m}$. Cells were allowed to attach while the tube rotated for $1 \mathrm{~h}$ at $0.5 \mathrm{rpm}$ and $37^{\circ} \mathrm{C}$. Subsequent static culture for four days allowed cell spreading and proliferation to create a confluent monolayer. Scale bar: $200 \mu \mathrm{m}$. After cell attachment, cells were cultured in a fluid flow bioreactor for seven days. The flow speed of the medium was raised slowly until the resulting wall shear stress of $1 \mathrm{~N} \mathrm{~m}^{-2}$ was achieved after 3.5 days, which is also experienced by endothelial cells in native capillaries [28]. We observed that endothelial cells aligned in the direction of the medium flow and changed their morphology to an elongated shape, while control cells cultured on TCPD conserved the cobblestone-like morphology, which is commonly observed in endothelia in static cultures. Specific markers for endothelial cells, CD31 and vWF, were expressed in both, the static and the dynamic regime (Figure 7).
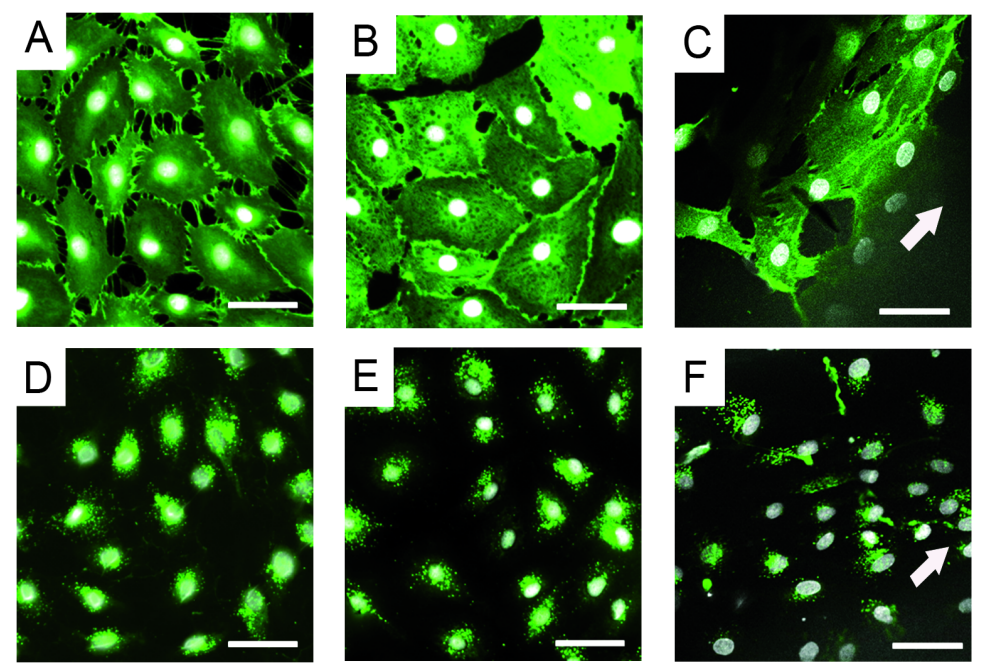

Figure 7. Expression of endothelial cell specific markers CD31 and vWF on thio-modified heparin/RGDC functionalized PA. 
HDMECs expressed CD31 and vWF when cultured under static and dynamic conditions: (A-C) CD31; (D-F) vWF; (A,D) static culture of HDMECs on TCPD (control); (B,E) static culture of HDMECs on PA functionalized with thio-modified heparin/RGDC; and $(\mathrm{C}, \mathrm{F})$ dynamic culture of HDMECs for seven days in a tubular PA material functionalized with thio-modified heparin/RGDC. Arrow shows the direction of flow (scale bar: $50 \mu \mathrm{m}$ ).

\subsection{Characterization of Hemolytic Potential and Platelet Adhesion}

With regard to future uses of endothelialized surfaces in direct contact with blood, we preliminary addressed hemocompatibility of PA and coated surfaces in terms of hemolysis and platelet adhesion. The hemolytic activity of all surfaces tested was below $1 \%$ of the positive control and none of the surfaces provoked any hemolysis significantly different from the negative control (Figure 8).
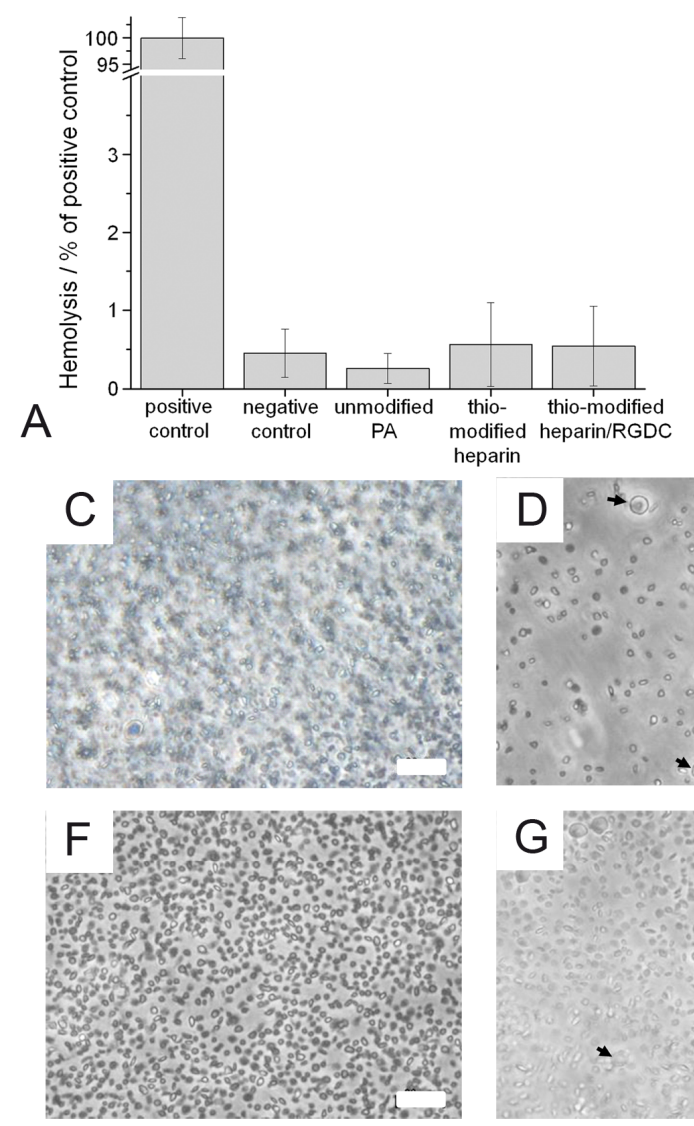
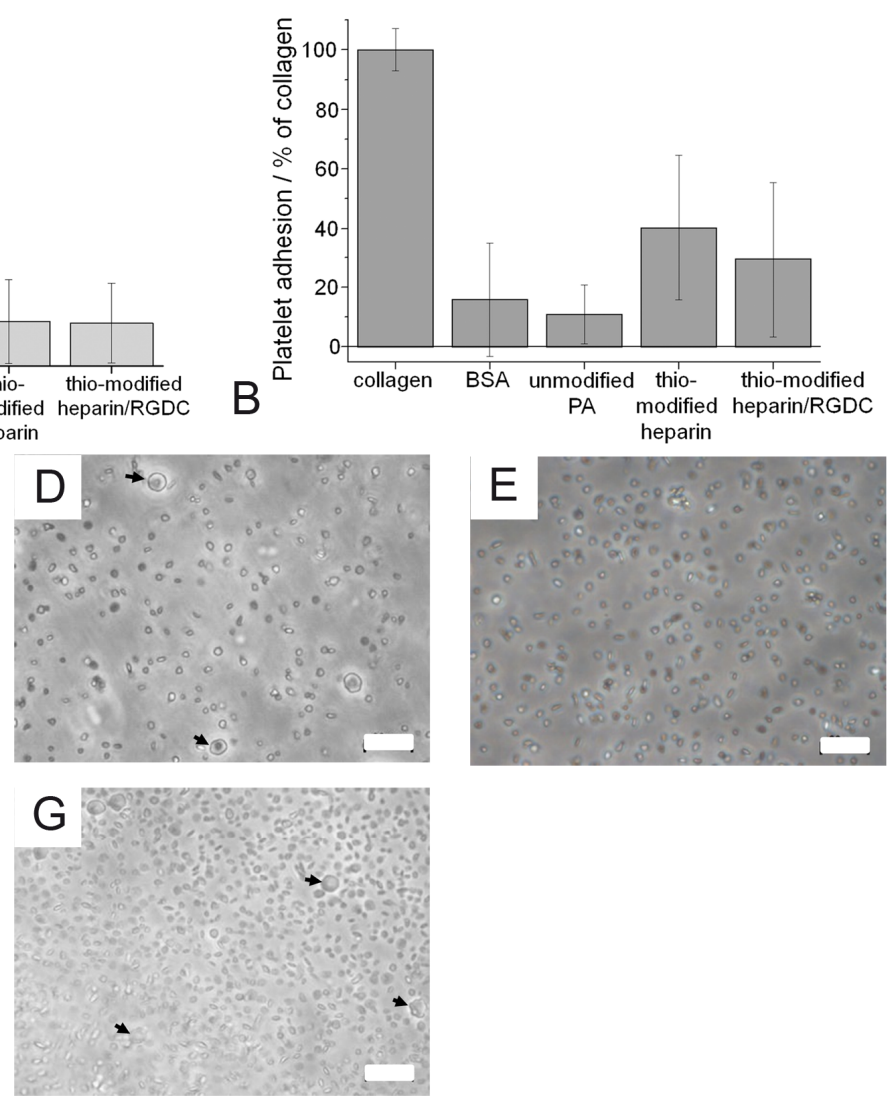

Figure 8. Hemolysis and platelet adhesion: (A) Hemolysis of erythrocytes on pristine and functionalized PA. Blood of three donors was tested on the materials in triplicates, and the results are shown as percentage of a positive control (erythrocytes lysed in water). For all tested materials the observed hemolytic activities were in the range of the negative control and $<1 \%$ in relation to the positive control. (B) Platelet adhesion to the various surfaces. The results are shown as percentage of LDH activity detected after lysis of adhered platelets, the positive control was the LDH activity of platelets adhered to collagen type I surfaces and was set to $100 \%$. BSA-coated TCPD served as negative control. (C) Platelets adhered to collagen type I; (D) BSA-coated TCPD; (E) unmodified PA; (F) PA functionalized with thio-modified heparin; and (G) PA functionalized with thio-modified heparin/RGDC. Activated platelets are marked with an arrow. Scale bar: $20 \mu \mathrm{m}$.

Light microscopic surface analysis revealed that the positive control surface (collagen type I) was densely covered with platelets, while considerably fewer platelets were found on the negative control (BSA-coated TCPD) and unmodified PA (Figure 8). On the surfaces functionalized with thio-modified 
heparin and thio-modified heparin/RGDC, more platelets adhered than to the unmodified PA. Very few activated platelets were observed. The relative quantification of adhered platelets was achieved by quantification of the amount of released LDH after platelet lysis (Figure 8). The results confirmed that platelet adhesion to unmodified PA $(10.9 \% \pm 9.8 \%)$ was similar to the negative control $(16.9 \% \pm 19.1 \%)$. Significantly higher numbers of platelets adhered to the coatings of thio-modified heparin $(40.2 \% \pm 23.6 \%)$. The adhesion to surfaces coated with thio-modified heparin/RGDC seemed to be at an elevated level $(29.4 \% \pm 26.0 \%)$ though not significant.

\section{Discussion}

Additive manufacturing methods are gaining importance in the fabrication of small-caliber artificial vascular grafts. Currenlty, no appropriate material is available that can be used in biological applications and in medical engineering in medicine. In this study, we investigated means to achieve cytocompatibility and biofunctionality of a new material formulation which was used to construct porous tubular structures with photo-curing based additive assembly by stereolithography.

\subsection{Post-Curing Treatments of UV-Cured PA}

We observed decreasing cytotoxicity upon extensive immersion $\mathrm{EtOH}(70 \%)$ suggesting that soluble substances with elevated toxicity, e.g., the photoinitiator Irgacure 184 which has been shown to be cytocompatible at low concentration $(<0.02 \%[29,30])$ or unreacted monomers remained within the polymer network after UV crosslinking and were then removed during rinsing. This observation was accompanied by a mass loss of $0.5 \%$ of the dried polymers before and after rinsing with EtOH. A moderate decrease of the Young's modulus and a strong dropping in tensile strength was also observed after the washing procedure with $\mathrm{EtOH}(70 \%)$ while a rise in the Young's modulus was observed upon exposure to PBS. We assume that microscopic destruction of the polymeric network occurred due to an elevated degree of swelling in EtOH. In spite of the hydrophobic properties of PA we detected a small uptake of $1 \%$ to $2 \%(\mathrm{w} / \mathrm{w})$ water into the polymer bulk material. Therefore, we propose that in the case of PBS the swelling effects resulted in an expanded (but not destructed) network with higher mechanical values.

The increase in modulus and tensile strength after $\gamma$-irradiation is assumed to be the result of increased degree of crosslinking of the polymer precursor molecules. The $\gamma$-radiation consists of higher energy and ingresses deeper into the material than UV radiation. Therefore, additional crosslinking of remaining monomers and elevated strength of the material has to be taken into account for $\gamma$-irradiated material in comparison to non-treated PA.

The elastic properties of native arteries are highly complex (anisotropy, viscoelasticity, and non-linear stress-strain relationship) and currently unmet by the use of synthetic materials. The material presented here was rather intended to provide adequate handling features required for mounting the perfusion systems into the bioreactor, than as proper mechanical model for blood vessels. The mechanical testing results showed that the solid cured-PA was sufficiently elastic and durable but surmounted the elasticity of natural blood vessels of around $2 \mathrm{MPa}$ only to some extent [31]. The properties of porous PA tubes will be characterized and adjusted in additional studies in terms of their mechanical answer to pulsed blood pressure and physical stretching.

\subsection{Production of Tubular Structures by Stereolithography}

The vertical resolution is a critical value for the generation of tubular structures by SLA. It is determined by the curing depth, which depends on the penetration depth of the employed wavelength within the photosensitive material. Thus, the curing depth can be minimized by increasing the absorption cross-section of the photosensitive material or by reducing the exposure from the SLA apparatus by, e.g., increasing the scanning speed. In our study, reduction of exposure and thus reduction of crosslinking density resulted in insufficient mechanical strength for the generation of 3D structures. Consequently, 2,2'-dihydroxy-4,4'-dimethoxy-benzophenon was added as an absorber to 
increase the absorption cross section of the photosensitive material. For this resin formulation the exposure and the curing depth showed the expected linear correlation on a semi-logarithmic scale. The deviation from the linear correlation for small exposures, i.e., high scanning speeds was most probably due to the fact that at a pulse repetition rate of $20 \mathrm{kHz}$ the pulse overlap was decreasing for the upper scan speeds. The lateral distance between two laser pulses at a scan speed of $400 \mathrm{~mm} \mathrm{~s}^{-1}$ was $20 \mu \mathrm{m}$ and therefore almost as large as the beam waist, such that the curing depth reached the minimum.

The freeform capabilities of the SLA process can be used to incorporate additional structural functionalities into the 3D tubular structure. For the generation of artificial supply systems for biological tissue models we chose to develop a hydrophobic material composition in order to avoid extensive swelling and thus geometrical changes of the tubes within aqueous environments. As a consequence, the vessel walls had to be porous in order to allow the free exchange of water and nutrients into and from surrounding tissue as well as the passage of cells, e.g., for neoangiogenesis. We demonstrated that the presented material process combination allowed for fabrication of tubular structures with well controlled $100 \mu \mathrm{m}$ pores.

In the future, the pore size must be reduced to $20 \mu \mathrm{m}$ or smaller to allow endothelial cells to cover the pores and to achieve a physiological barrier controlled by the endothelial layer [32,33]. Currently, higher resolutions required reduced laser intensities and thus resulted in decreased mechanical stabilities. In order to overcome such hurdles, further tuning of material properties and curing parameters will be addressed in future studies.

\subsection{PA Surface Functionalization with Thio-Modified Heparin and RGDC-Peptides}

Endothelial cells are known to bind to proteins from the basement membrane (e.g., collagens, laminin, perlecan, and fibronectin), serum proteins (fibrin and fibrinogen) or the respective integrin-binding epitopes including RGD, YIGSR, and GFOGER [34-36]. Some studies reported that coating with heparin improved EC adhesion to surfaces. The interaction of surface bound heparin with the heparin-binding domain of fibronectin is discussed as one possible mechanism mediating cell adhesion [37], but the interaction of heparin with endothelial cells is not completely understood yet [38-40] and most studies heparin-based coatings alone only supported initial cell adhesion but cell loss and irregular cell shapes were observed after some time [37]. In order to achieve stable endothelial lining of the tube surfaces we combined heparin with RGD peptide coupling. We used thio-modified heparin and RGD-cysteine to modify the PA surfaces. PA surfaces eventually contain unreacted acrylate functions $(C=C)$ after curing [26]. Such remaining double bounds (RDB) can be used for the conjugation of thio-functional molecules via thiol-Michael reactions. Although the covalent coupling of thio-functions to acrylate functions at the PA surface could not be deduced from XPS data directly, the increase in Sulfur (S) content and the change in N:S ratio at the PA surface indicated heparin immobilization and RGDC coupling, respectively. While in our hands the direct coupling of the cysteine to the PA surface was not efficient the thio-functionalized heparin polymers obviously mediated subsequent coupling of RGDC. We concluded that the thiolated polymer chains, once they bound to acrylic functions at the PA surface, served as multiplicator displaying a high number of thio-functions for RGDC coupling via disulfide formation.

\subsection{Endothelial Cell Culture on Planar and Tubular Substrates}

The effective contribution of short recognition sites such as RGD to cell adhesion in protein-rich environments as in vivo is discussed controversial [41]. However, in vitro RGD is one of the most often used cell recognition sequences. It was shown in several studies that RGD enhanced endothelial cell attachment [42-45]. In accordance with our own results other studies that combined heparin-based coatings with specific cell adhesion sequences such as fibronectin or RGD, the addition of cell adhesion sites stabilized or improved $[37,38,40]$ the adhesion of endothelial cells. 
In our hands rotating seeding led to a complete homogenous monolayer of endothelial cells on the heparin-RGD functionalized inner tube wall. We have shown that endothelial cells stayed attached and aligned along the media flow even after culturing them for 7 days under fluid flow, thereby applying the physiological wall shear stress of $1 \mathrm{~N} \mathrm{~m}^{-2}$ for 2 days. Previous studies had also shown that endothelial cells, e.g., adhered on RGD-functionalized expanded polytetrafluoroethylene grafts (ePTFE) and oriented in the direction of shear stress and formed a cell layer more resistant to

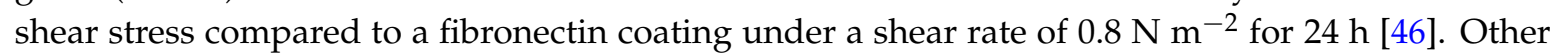
authors showed that cells adherent to a RGD-coated polyethylene terephthalate (PET) surface endured exposure to $12 \mathrm{dyn} \mathrm{cm}^{-2}\left(1.2 \mathrm{~N} \mathrm{~m}^{-2}\right)$ shear stress, mimicking arterial conditions, for two hours [47]. A higher seeding efficiency was additionally observed when using endothelial progenitor cells on RGD-coated surfaces compared to human umbilical vein endothelial cells (HUVECs) [48].

\subsection{Characterization of Hemolytic Potential and Platelet Adhesion}

Although intended for in vitro use in its current state, we also assessed the new PA material and its coatings in a preliminary study with regard to hemolytic and platelet-adhesive effects. As expected, none of the surfaces showed hemolytic activities. However, thio-modified heparin as well as heparin/RGDC coated surfaces seemed to slightly mediate platelet adhesion in contrast to unmodified PA. It is known that contact activation of platelet integrins, e.g., by the RGD sequence generally leads to platelet adhesion, spreading and thrombus formation at surfaces [49-52]. Interestingly, some in vivo experiments also proofed reduction of platelet adhesion on RGD functionalized surfaces compared to unmodified polymers such as PCL [53].

Profound platelet adhesion to thiol-groups was also reported for thiolated surfaces that carried low surface charge densities [54]. It is discussed to be mediated by the existence of free thiol-groups on the surface of platelets $[55,56]$. The surfaces described here also allow for the assumption that masking of free thio-groups of thio-modified heparin has occurred by RGDC peptide coupling via disulfide formation and may have thereby reduced platelet adhesion. Still, the thrombogenic potential of the surface stayed on an elevated level consistent with the observation of other authors, who reported $\alpha \mathrm{IIb} \beta 3$ integrin mediated adhesion of platelets to the RGD sequence [52]. In contrast to the results of Corum et al. hydrophobicity of the untreated PA alone did not result in elevated platelet adhesion [54].

\section{Experimental Section}

\subsection{Preparation of (co-BPA-co-IBA-co-IL)-Polyacrylate in Planar and Tubular Geometry}

Bisphenol A ethoxylate diacrylate $\left(M=688 \mathrm{~g} \mathrm{~mol}^{-1}\right)$ (BPA), lauryl acrylate (LA), and isobornyl acrylate (IBA) were purchased from Sigma Aldrich ${ }^{\circledR}$; Irgacure ${ }^{\circledR} 184$ was used as photoinitiator (kindly provided by Ciba AG, Basel, Switzerland). First, 49.75\% BPA, 37.31\% IBA, 12.44\% IL and 0.5\% Irgacure ${ }^{\circledR}$ 184 were blended (PA-resin) and used for sample preparation by curing with UV light under an argon atmosphere. The cured polyacrylate, a statistical (co-BPA-co-IBA-co-IL)-polyacrylate (PA), has been described recently [57].

\subsubsection{Planar Sample Preparation}

The volume of $0.3 \mathrm{~mL}$ PA-resin was loaded into a polystyrene petri dish (diameter $35 \mathrm{~mm}$ ), flushed with argon, and irradiated 4 min with full UV spectra (Bluepoint 4 ecocure, Hoenle, Germany: $40 \mathrm{~mW} \mathrm{~cm}^{-2}$ at $365 \mathrm{~nm}$ ).

\subsubsection{Tubular Sample Preparation by Dip Coating}

Small glass rods ( $d=2 \mathrm{~mm}, L=75 \mathrm{~mm}$; Marienfeld, Lauda-Königshofen, Germany) were dip coated manually into PA-resin, led drop off surplus material while smoothly turning the tubes between two fingers, placed in a glass beaker and UV cured for approximately 1 min while permanently flushed with argon. The procedure was repeated six times. Subsequently, these multilayers were flushed with 
argon and irradiated for $4 \mathrm{~min}$. The PA coated glass rod was left in water overnight to separate the coating easily from the glass rod remaining PA tubes with $2 \mathrm{~mm}$ inner diameter.

\subsubsection{Tubular Sample Preparation by SLA}

For the preparation of AM generated tubular samples an SLA setup was used. An UV laser source (FTSS 355-Q2, CryLaS GmbH, Berlin, Germany) emitting laser pulses with a pulse duration of approximately $1 \mathrm{~ns}$ at a wavelength of $355 \mathrm{~nm}$ was focused by a f-Theta lens with a focal length of $100 \mathrm{~mm}$ (JENar ${ }^{\circledR}$ 03-70FT-100-355, JENOPTIK Optical Systems Inc., Jena, Germany). The laser focus can be translated using a scanner system (PS2-10, Cambridge Technology, Planegg, Germany) and yields a maximum working field of $52 \mathrm{~mm} \times 52 \mathrm{~mm}$. The resulting beam waist was measured by a beam analyzing camera (SP620U, Ophir Optronics Solutions Ltd., Darmstadt, Germany) to approximately $30 \mu \mathrm{m}$. For sample preparation, the laser source was set to a repetition rate of $20 \mathrm{kHz}$ and the photosensitive resin was placed in a small volume vat. For SLA, $0.1 \%(\mathrm{w} / \mathrm{w})$ of 2,2'-dihydroxy-4,4'-dimethoxy-benzophenon was added to the resin as an absorber to reduce the curing depth. The tubular structures were built in a layer-by-layer approach, with a layer separation distance of $20 \mu \mathrm{m}$. The curing depth $C_{D}$ was determined for different exposures $\mathrm{E}$ applying the following equation [58]:

$$
C_{D}=D_{P} \times \ln \left(\frac{E}{E_{\text {crit }}}\right)
$$

where $D_{P}$ denotes the penetration depth at which the initial intensity is reduced to $1 / \mathrm{e}(\sim 37 \%)$ and $E_{c r i t}$ is the critical exposure necessary to initiate polymerization.

\subsection{Sterilization}

Gamma $(\gamma)$-sterilization for the mechanical tests was performed by a certified commercial service provider (BBF Sterilisationsservice $\mathrm{GmbH}$, Kernen-Rommelshausen, Germany) at approximately $30 \mathrm{kGy}$.

\subsection{Characterization of Young's Modulus and Tensile Strength of PA}

Samples were cured using full spectra UV in a silicon bone template for 4 min under argon atmosphere and measured with Zwick/Roell 1445 (Zwick, Ulm, Germany). Samples were prepared with: (a) no further treatment; (b) after $\gamma$-sterilization; (c) washed for five days in $70 \% \mathrm{EtOH}$ then dried in vacuum overnight at $40^{\circ} \mathrm{C}$; and (d) like (c), followed by exposing to PBS buffer for $24 \mathrm{~h}$.

\subsection{Evaluation of the Cytocompatibility}

The cytocompatibility of post-cured PA was characterized according to DIN ISO 10993-5 [27]. For extract preparation planar PA samples were covered with $3 \mathrm{~mL}$ DMEM (Biochrom, Berlin, Germany) for $24 \mathrm{~h}$ at $37^{\circ} \mathrm{C}$ under static conditions. Human dermal fibroblasts were seeded in 96-well tissue culture polystyrene plates $\left(10^{4}\right.$ cells per well). PA extracts were then pipetted onto the cell cultures (200 $\mu \mathrm{L}$ per well), $10 \%$ FCS per well was added and cells were incubated for $24 \mathrm{~h}$ at $37^{\circ} \mathrm{C}$. Cells incubated in DMEM were provided as a negative control. The cell viability was determined by WST-1 assay (Roche, Mannheim, Germany) according to the manufacturer's protocol using a microplate reader (Infinite 200 Pro, Tecan, Crailsheim Germany). Mass loss (\%) was calculated from tubular PA samples $(n=12)$. The vacuum dried mass was determined before and after extracting tubes with $70 \%$ EtOH for a period of five days:

$$
\% \text { mass loss }=\left(\frac{m(\text { PA tube })_{\text {after }}}{m(\text { PA tube })_{\text {before }}}\right) \times 100
$$




\subsection{Synthesis of 3,3-Dithiobis(Propanoic Dihydrazide) (DTPH)}

The synthesis was performed based on Vercruysse et al. [59]. Five grams of 3,3- dithiodipropionic acid were diluted in $40 \mathrm{~mL}$ absolute methanol with a few drops of oleum. The mixture was refluxed under argon for $1 \mathrm{~h}$. The reaction mixture was concentrated to $10 \mathrm{~mL}$ volume, diluted in ethylacetate and washed with $1 \mathrm{M} \mathrm{NaOH}$ and water. The organic phase was dried in vacuum to yield the ester. Five grams of the product were dissolved in $40 \mathrm{~mL}$ ethanol $(\mathrm{EtOH})$ and added to $15.75 \mathrm{~g}$ hydrazine hydrate. The solution was warmed up, stirred for $4 \mathrm{~h}$, and the product was then precipitated through cooling to $4{ }^{\circ} \mathrm{C}$. The filtered and washed crystals were dried under vacuum. 1H-NMR: (DMSO-d6) $\delta 9.07\left(\mathrm{~s}, 2 \mathrm{H}, \mathrm{NH}_{2}-\mathrm{NH}-\mathrm{CO}-\right), 4.20\left(\mathrm{~s}, 4 \mathrm{H}, \mathrm{NH}_{2}-\mathrm{NH}-\right), 2.89\left(\mathrm{t}, 4 \mathrm{H}, \mathrm{S}-\mathrm{CH}_{2}-\right), 2.41\left(\mathrm{t}, 4 \mathrm{H},-\mathrm{CH}_{2}-\mathrm{CO}-\right)$.

\subsection{Synthesis and Characterization of Thio-Modified Heparin}

Heparin sodium salt was chemically modified following Shu et al. [60]. Briefly, $476 \mathrm{mg}$ DTPH were dissolved in $20 \mathrm{~mL}$ double distilled water $\left(\mathrm{ddH}_{2} \mathrm{O}\right)$. Five hundred milligrams heparin (CAS 01.08.9041, Aldrich, Germany) and $192 \mathrm{mg}$ 1-Ethyl-3-(3-dimethylaminopropyl) carbodiimid (EDC, CAS 25952-53-8, Fluka, Darmstadt, Germany) were added and the reaction mixture was stirred for $4 \mathrm{~h}$ at $\mathrm{pH} 4.75$, then increased to $\mathrm{pH} 8$. Then, $1.54 \mathrm{~g}$ dithiothreitol (DTT) were added and stirred overnight. The solution was dialyzed first in $0.3 \mathrm{M} \mathrm{NaCl}$ solution with $0.1 \%$ benzyl alcohol at $\mathrm{pH} 3.5$, then in $\mathrm{ddH}_{2} \mathrm{O}$ with $0.1 \%$ benzyl alcohol at $\mathrm{pH} 3.5$, and then in $\mathrm{ddH}_{2} \mathrm{O}$. The purity of the product and the substitution of thio-groups were verified by $1 \mathrm{H}-\mathrm{NMR}$.

\subsection{PA Surface Functionalization with Thio-Modified Heparin and RGDC-Peptides}

For surface functionalization with thio-modified heparin or RGDC peptides, PA was incubated overnight with thio-modified heparin $\left(2 \mathrm{mg} \mathrm{mL}^{-1}\right)$ or RGDC $\left(0.2 \mathrm{mg} \mathrm{mL}^{-1}\right)$ in PBS buffer (pH 7.2) at room temperature (RT) on a shaker. Afterwards, the samples were washed three times with $\mathrm{ddH}_{2} \mathrm{O}$. Sequential functionalization of PA surfaces with thio-modified heparin and RGDC via disulfide formation was performed according to Kirihara et al. [61]. After immobilization of thio-modified heparin, the samples were immersed at RT with $0.25 \mathrm{mg} \mathrm{mL}^{-1} \mathrm{RGDC}, 0.125 \mathrm{nmol} \mathrm{mL}{ }^{-1}$ potassium iodide (Fluka, Darmstadt, Germany) and 3\% hydrogen oxide $\left(14.7 \mu \mathrm{mol} \mathrm{mL}{ }^{-1}\right.$, Sigma-Aldrich, Germany) and shaken for $10 \mathrm{~h}$. Subsequently, the samples were rinsed with $\mathrm{ddH}_{2} \mathrm{O}$. For disinfection, all samples were incubated with $70 \% \mathrm{EtOH}$ for $0.5 \mathrm{~h}$ before seeding of cells.

\subsection{Endothelial Cell Culture on Planar and Tubular Substrates}

\subsubsection{Cell Culture on Planar Substrates}

Human dermal microvascular endothelial cells (HDMECs) were seeded at a density of $10^{5}$ cells on planar PA samples per dish (diameter: $35 \mathrm{~mm}$ ) in endothelial cell growth medium (ECGMmv) media (PromoCell, Heidelberg, Germany) to evaluate cell adhesion and proliferation. Cells were incubated at $37^{\circ} \mathrm{C}$ for $24 \mathrm{~h}$ and then analyzed by bright-field microscopy (Nikon, Düsseldorf, Germany).

\subsubsection{Cell Culture on Tubular Substrates}

HDMECs were seeded to the inner walls of tubular scaffolds at $8 \times 10^{6} \mathrm{HDMECs} \mathrm{mL}^{-1}$ using either a static set up or rotating the tube at $0.5 \mathrm{rpm}$ for $1 \mathrm{~h}$ (porous tubes) or $4 \mathrm{~h}$ (non-porous tubes) at $37^{\circ} \mathrm{C}$. Porous tubes were then statically cultured for four days to allow cell proliferation.

For dynamic culture of HDMECs in tubes, a fluid flow bioreactor (Unitechnologies SA, Gals, Switzerland) was used. Upon adhesion, HDMECs were cultured experiencing a wall shear stress of $0.012 \mathrm{~N} \mathrm{~m}^{-2}$ for $24 \mathrm{~h}$. The shear stress was then increased at a rate of $0.012 \mathrm{~N} \mathrm{~m}^{-2} \mathrm{~h}^{-1}$ up to the maximum of $1 \mathrm{~N} \mathrm{~m}^{-2}$, which is comparable to the shear stress experienced by endothelial cells in native capillaries [28]. 
Laminar wall shear rate was calculated as followed:

$$
\tau_{\text {wall }}=\frac{4 \times \bar{v} \times \eta}{r_{i}}
$$

where $\tau_{\text {wall }}$ in $\mathrm{N} \mathrm{m}^{-2}$ is the wall shear rate, $\bar{v}$ in $\mathrm{m} \mathrm{s}$ is the velocity of the fluid, $\eta$ in $\mathrm{Ns} \mathrm{m}^{-2}$ is the dynamic viscosity of the fluid and $r_{i}$ in $\mathrm{m}$ is the inner radius of the tube.

The cells were cultured for $48 \mathrm{~h}$ with a wall shear rate of $1 \mathrm{~N} \mathrm{~m}^{-2}$. During 7 days two media exchanges were performed.

\subsection{Staining of Cells}

For the detection of viable cells within the tubes, 3-(4, 5-dimethylthiazolyl-2)-2,5- diphenyl tetrazolium bromide (1 mg mL ${ }^{-1}$; MTT; Sigma-Aldrich, Taufkirchen, Germany) in ECGMmv medium (PromoCell, Germany) was pipetted into the tubes and incubated for $45 \mathrm{~min}$ at $37^{\circ} \mathrm{C}$. For immunofluorescence staining of the endothelial cell marker CD31 and von Willebrand Factor (vWF) cells were fixed using 4\% phosphate-buffered formaldehyde (Roth, Karlsruhe, Germany) for $15 \mathrm{~min}$. Prior to blocking with 3\% BSA/PBS for $30 \mathrm{~min}$, cells for vWF staining were permeabilized using a PBS/0, 1\% Triton-X-100 (Sigma-Aldrich, Taufkirchen, Germany) solution for $10 \mathrm{~min}$ at RT. Primary antibodies were diluted with antibody diluent (all DAKO, Germany; vWF: 1:600; CD31: 1:800) and incubated overnight at $4{ }^{\circ} \mathrm{C}$. Then, Cy3-labeled secondary antibody (1:1000; Jackson Immuno Research, Suffolk, UK) was applied for $0.5 \mathrm{~h}$. Nuclei were stained with DAPI (1:1000) for $15 \mathrm{~min}$ in the dark and cells were analyzed in $\mathrm{PBS}^{+}$with a laser scanning microscope (Zeiss, Jena, Germany).

\subsection{Hemolysis and Platelet Adhesion}

Hemolysis and platelet adhesion were assessed as described in Motlagh et al. [62]. For hemolysis testing, heparinized blood from three healthy volunteers was used. All samples were probed with blood from each donor in triplicates. Briefly, $0.4 \mathrm{~mL}$ whole blood was diluted in $20 \mathrm{~mL}$ physiologic salt solution. One milliliter was pipetted onto each sample or into tissue culture petri dishes (TCPD; negative control) in triplicates. Complete lysis of the erythrocytes was achieved by addition of $10 \mathrm{~mL}$ sterile $\mathrm{ddH}_{2} \mathrm{O}$ to $0.2 \mathrm{~mL}$ donor blood (positive control on TCPD). All samples were incubated under gentle agitation for $2 \mathrm{~h}$ at $37^{\circ} \mathrm{C}$. Afterwards, the blood dilutions were centrifuged at $13,250 \mathrm{~g}$ for $10 \mathrm{~min}$. Absorbance of released hemoglobin was measured at $541 \mathrm{~nm}$ in 96-well plates using a microplate reader (Infinite 200 Pro, TECAN, Crailsheim, Germany). The percentage of hemolysis was calculated as follows:

$$
\% \text { Hemolysis }=\frac{\text { absorbance of test polymer }}{\text { absorbance of positive control }} \times 100
$$

For platelet adhesion testing, human platelet concentrates (HPC; leukocyte-depleted, each pooled from four donors) were purchased from the Institute for Transfusion Medicine of the Katharinenhospital (Klinikum Stuttgart, Stuttgart, Germany). Six independent experiments were conducted, each including all material samples in triplicates. Collagen gels $\left(6 \mathrm{mg} \mathrm{mL}^{-1}\right.$; Fraunhofer IGB, Stuttgart, Germany) on TCPD served as positive control, TCPD surfaces modified with BSA (40\%) were used as negative control [63]. Cell counting of the HPCs resulted in counts between $7.97 \times 10^{6}$ cells $\mathrm{mL}^{-1}$ and $8.79 \times 10^{6}$ cells $\mathrm{mL}^{-1}$. In total, $250 \mu \mathrm{L} \mathrm{cm}^{-2} \mathrm{HPC}$ were incubated on every sample at $37^{\circ} \mathrm{C}$ for $1 \mathrm{~h}$. The surfaces were carefully washed three times with PBS to remove non-adhered platelets. Light-microscopic pictures were taken (Nikon, Germany). Subsequently, the adhered cells were lysed with PBS $/ 2 \%$ Triton-X- 100 at $37^{\circ} \mathrm{C}$ for $30 \mathrm{~min}$. Lactate dehydrogenase (LDH) activity (in Unit $\mathrm{L}^{-1}$ ) was assessed from supernatants with the RX Daytona analyzer (Randox, Crumlin, United Kingdom). Platelet adhesion was calculated in correlation to the platelets that adhered to the positive control as follows:

$$
\% \text { Platelet adhesion }=\frac{\text { LDH activity on tested sample }}{\text { LDH activity on collagen }} \times 100
$$




\section{Conclusions}

The presented material system consisting of a photo-crosslinkable polymer resin, which forms a cytocompatible elastic polymer upon UV curing, and a biofunctional coating contributes to the development of a new class of materials that fulfill a range of current demands associated with biomaterials. In particular, fabrication of complex structures comes more and more into focus, in addition to non-toxicity, sterilizability and the potential to achieve genuine biological surfaces, i.e., endothelialization. In this study, we present a polyacrylate resin that can be photo-cured to generate scaffolds in various geometries using a photoinitiator and UV irradiation. We fabricated complex tubular structures with multiple branches and defined pores by stereolithography and achieved biofunctionalization and confluent endothelial lining of the inner tube walls within a flow bioreactor. In conclusion, we provide a technology platform that enables additive freeform fabrication of complex cytocompatible objects covering structure sizes from the $\mu \mathrm{m}$ range to $\mathrm{cm}$ range with biofunctional surfaces, and thus being promising for sophisticated scaffolding for in vitro tissue models and for individualized medical engineering.

Acknowledgments: The authors thank Esther Novosel (Xenios AG, Germany, former University of Stuttgart, Germany) for providing data on cytocompatibility testing and analysis of surface coatings, Xiaoxiao Han (University of Loughborough, UK) and Eero Huotilainen (Aalto University, Finland) for providing STL files for the fabrication of branched tubular structures, and Iván Calderon (Unitechnologies SA, Switzerland) for the planning and construction of the used bioreactor. Thanks to Diana Mang (Fraunhofer IAP) and Richard Kudiabor (Fraunhofer ILT) for her manual skills and laboratory help. We gratefully acknowledge the European Commission for funding the ArtiVasc 3D project under the Seventh Framework Program (grant agreement n263416).

Author Contributions: Günter E. M. Tovar, Petra J. Kluger, Hartmut Krüger, and Kirsten Borchers conceived and designed the experiments; Birgit Huber, Sascha Engelhardt, Veronika Schönhaar, Wolfdietrich Meyer, and Annika Wenz performed the experiments and analyzed the data; and Birgit Huber and Kirsten Borchers wrote the paper.

Conflicts of Interest: The authors declare no conflict of interest.

\section{References}

1. Rose, A.S.; Webster, C.E.; Harrysson, O.L.A.; Formeister, E.J.; Rawal, R.B.; Iseli, C.E. Pre-operative simulation of pediatric mastoid surgery with 3D-printed temporal bone models. Int. J. Pediatr. Otorhinolaryngol. 2015, 79, 740-744. [CrossRef] [PubMed]

2. Kurenov, S.N.; Ionita, C.; Sammons, D.; Demmy, T.L. Three-dimensional printing to facilitate anatomic study, device development, simulation, and planning in thoracic surgery. J. Thorac. Cardiovasc. Surg. 2015, 149, 973-979. [CrossRef] [PubMed]

3. Melchels, F.P.W.; Domingos, M.; Klein, T.J.; Malda, J.; Bartolo, P.J.; Hutmacher, D.W. Additive manufacturing of tissues and organs. Prog. Polym. Sci. 2012, 37, 1079-1104. [CrossRef]

4. Salacinski, H.J.; Goldner, S.; Giudiceandrea, A.; Hamilton, G.; Seifalian, A.M.; Edwards, A.; Carson, R.J. The mechanical behavior of vascular grafts: A review. J. Biomater. Appl. 2001, 15, 241-278. [CrossRef] [PubMed]

5. Baiguera, S.; Ribatti, D. Endothelialization approaches for viable engineered tissues. Angiogenesis 2013, 16, 1-14. [CrossRef] [PubMed]

6. Zhu, M.; Wang, K.; Mei, J.; Li, C.; Zhang, J.; Zheng, W.; An, D.; Xiao, N.; Zhao, Q.; Kong, D.; et al. Fabrication of highly interconnected porous silk fibroin scaffolds for potential use as vascular grafts. Acta Biomater. 2014, 10, 2014-2023. [CrossRef] [PubMed]

7. De Valence, S.; Tille, J.C.; Giliberto, J.P.; Mrowczynski, W.; Gurny, R.; Walpoth, B.H.; Möller, M. Advantages of bilayered vascular grafts for surgical applicability and tissue regeneration. Acta Biomater. 2012, 8, 3914-3920. [CrossRef] [PubMed]

8. Sill, T.J.; von Recum, H.A. Electro spinning: Applications in drug delivery and tissue engineering. Biomaterials 2008, 29, 1989-2006. [CrossRef] [PubMed]

9. Zhang, Y.; Yu, Y.; Ozbolat, I.T. Direct bioprinting of vessel-like tubular microfluidic channels. J. Nanotechnol. Eng. Med. 2013, 4, 020902-020910. [CrossRef] 
10. Luo, Y.; Lode, A.; Gelinsky, M. Direct plotting of three-dimensional hollow fiber scaffolds based on concentrated alginate pastes for tissue engineering. Adv. Healthc. Mater. 2013, 2, 777-783. [CrossRef] [PubMed]

11. Bettinger, C.J.; Cyr, K.M.; Matsumoto, A.; Langer, R.; Borenstein, J.T.; Kaplan, D.L. Silk fibroin microfluidic devices. Adv. Mater. 2009, 19, 2847-2850. [CrossRef] [PubMed]

12. Bettinger, C.J.; Weinberg, E.J.; Kulig, K.M.; Vacanti, J.P.; Wang, Y.; Borenstein, J.T.; Langer, R. Three-dimensional microfluidic tissue-engineering scaffolds using a flexible biodegradable polymer. Adv. Mater. 2005, 18, 165-169. [CrossRef] [PubMed]

13. Fidkowski, C.; Kaazempur-Mofrad, M.R.; Borenstein, J.; Vacanti, J.P.; Langer, R.; Wang, Y. Endothelialized microvasculature based on a biodegradable elastomer. Tissue Eng. 2005, 11, 302-309. [CrossRef] [PubMed]

14. Borenstein, J.T.; Tupper, M.M.; Mack, P.J.; Weinberg, E.J.; Khalil, A.S.; Hsiao, J.; García-Cardeña, G. Functional endothelialized microvascular networks with circular cross-sections in a tissue culture substrate. Biomed. Microdevices 2010, 12, 71-79. [CrossRef] [PubMed]

15. Hoch, E.; Tovar, G.E.; Borchers, K. Bioprinting of artificial blood vessels: Current approaches towards a demanding goal. Eur. J. Cardiothorac Surg. 2014, 46, 767-778. [CrossRef] [PubMed]

16. Bellan, L.M.; Pearsall, M.; Cropek, D.M.; Langer, R. A 3D interconnected microchannel network formed in gelatin by sacrificial shellac microfibers. Adv. Mater. 2012, 24, 5187-5191. [CrossRef] [PubMed]

17. Lee, W.; Lee, V.; Polio, S.; Keegan, P.; Lee, J.H.; Fischer, K.; Park, J.K.; Yoo, S.S. On-demand three-dimensional freeform fabrication of multi-layered hydrogel scaffold with fluidic channels. Biotechnol. Bioeng. 2010, 105, 1178-1186. [CrossRef] [PubMed]

18. Miller, J.S.; Stevens, K.R.; Yang, M.T.; Baker, B.M.; Nguyen, D.-H.T.; Cohen, D.M.; Toro, E.; Chen, A.A.; Galie, P.A.; Yu, X.; et al. Rapid casting of patterned vascular networks for perfusable engineered three-dimensional tissues. Nat. Mater. 2012, 11, 768-774. [CrossRef] [PubMed]

19. Xu, C.; Chai, W.; Huang, Y.; Markwald, R.R. Scaffold-free inkjet printing of three-dimensional zigzag cellular tubes. Biotechnol. Bioeng. 2012, 109, 3152-3160. [CrossRef] [PubMed]

20. Nakamura, M.; Nishiyama, Y.; Henmi, C.; Iwanaga, S.; Nakagawa, H. Ink jet three-dimensional digital fabrication for biological tissue manufacturing: Analysis of alginate microgel beads produced by ink jet droplets for three dimensional tissue fabrication. J. Imaging Sci. Technol. 2008, 52, 1-16. [CrossRef]

21. Visser, J.; Peters, B.; Burger, T.J.; Boomstra, J.; Dhert, W.J.; Melchels, F.P.; Malda, J. Biofabrication of multi-material anatomically shaped tissue constructs. Biofabrication 2013, 5, 1-9. [CrossRef] [PubMed]

22. Li, S.; Xiong, Z.; Wang, X.; Yan, Y.; Liu, H.; Zhang, J. Direct fabrication of a hybrid cell/hydrogel construct by a double-nozzle assembling technology. J. Bioact. Compat. Polym. 2009, 24, 249-265.

23. Meyer, W.; Engelhardt, S.; Novosel, E.; Elling, B.; Wegener, M.; Krüger, H. Soft polymers for building up small and smallest blood supplying systems by stereolithography. J. Funct. Biomater. 2012, 3, 257-268. [CrossRef] [PubMed]

24. Baudis, S.; Nehl, F.; Ligon, S.C.; Nigisch, A.; Bergmeister, H.; Bernhard, D.; Stampfl, J.; Liska, R. Elastomeric degradable biomaterials by photopolymerization-based cad-cam for vascular tissue engineering. Biomed. Mater. 2011, 6, 055003-055008. [CrossRef] [PubMed]

25. Engelhardt, S.; Hoch, E.; Borchers, K.; Meyer, W.; Krüger, H.; Tovar, G.E.; Gillner, A. Fabrication of 2D protein microstructures and 3D polymer-protein hybrid microstructures by two-photon polymerization. Biofabrication 2011, 3, 025003. [CrossRef] [PubMed]

26. Novosel, E.C.; Meyer, W.; Klechowitz, N.; Krüger, H.; Wegener, M.; Walles, H.; Tovar, G.E.; Hirth, T.; Kluger, P.J. Evaluation of cell-material interactions on newly designed, printable polymers for tissue engineering applications. Adv. Eng. Mater. 2011, 13, B467-B475. [CrossRef]

27. ISO 10993-5:2009(en)-Biological Evaluation of Medical Devices; ISO: Geneva, Switzerland, 2009.

28. Fisher, A.B.; Chien, S.; Barakat, A.I.; Nerem, R.M. Endothelial cellular response to altered shear stress. Am. J. Physiol. Lung Cell. Mol. Physiol. 2001, 281, L529-L533. [PubMed]

29. Williams, C.G.; Malik, A.N.; Kim, T.K.; Manson, P.N.; Elisseeff, J.H. Variable cytocompatibility of six cell lines with photoinitiators used for polymerizing hydrogels and cell encapsulation. Biomaterials 2005, 26, 1211-1218. [CrossRef] [PubMed]

30. Bryant, S.J.; Nuttelman, C.R.; Anseth, K.S. Cytocompatibility of UV and visible light photoinitiating systems on cultured NIH/3T3 fibroblasts in vitro. J. Biomater. Sci. Polym. Edit. 2000, 11, 439-457. [CrossRef] 
31. Schmidt, D.; Asmis, L.M.; Odermatt, B.; Kelm, J.; Breymann, C.; Gössi, M.; Genoni, M.; Zund, G.; Hoerstrup, S.P. Engineered living blood vessels: Functional endothelia generated from human umbilical cord-derived progenitors. Ann. Thorac. Surg. 2006, 82, 1465-1471. [CrossRef] [PubMed]

32. Mathews, A.; Colombus, S.; Krishnan, V.K.; Krishnan, L.K. Vascular tissue construction on poly(e-caprolactone) scaffolds by dynamic endothelial cell seeding: Effect of pore size. J. Tissue Eng. Regen. Med. 2012, 6, 451-461. [CrossRef] [PubMed]

33. Narayan, D.; Venkatraman, S.S. Effect of pore size and interpore distance on endothelial cell growth on polymers. J. Biomed. Mater. Res. A 2008, 87, 710-718. [CrossRef] [PubMed]

34. Von der Mark, K.; Park, J.; Bauer, S.; Schmuki, P. Nanoscale engineering of biomimetic surfaces: Cues from the extracellular matrix. Cell Tissue Res. 2010, 339, 131-153. [CrossRef] [PubMed]

35. Jung, J.P.; Moyano, J.V.; Collier, J.H. Multifactorial optimization of endothelial cell growth using modular synthetic extracellular matrices. Integr. Biol. (Camb) 2011, 3, 185-196. [CrossRef] [PubMed]

36. Hayashi, K.; Madri, J.A.; Yurchenco, P.D. Endothelial-cells interact with the core protein of basementmembrane perlecan through beta- 1 and beta-3 integrins-An adhesion modulated by glycosaminoglycan. J. Cell Biol. 1992, 119, 945-959. [CrossRef] [PubMed]

37. Bos, G.W.; Scharenborg, N.M.; Poot, A.A.; Engbers, G.H.; Terlingen, J.G.; Beugeling, T.; Van Aken, W.G.; Feijen, J. Adherence and proliferation of endothelial cells on surface-immobilized albumin-heparin conjugate. Tissue Eng. 1998, 4, 267-279. [CrossRef] [PubMed]

38. Tiwari, A.; Salacinski, H.J.; Punshon, G.; Hamilton, G.; Seifalian, A.M. Development of a hybrid cardiovascular graft using a tissue engineering approach. FASEB J. 2002, 16, 791-796. [CrossRef] [PubMed]

39. Pan, C.J.; Hou, Y.H.; Zhang, B.B.; Dong, Y.X.; Ding, H.Y. Blood compatibility and interaction with endothelial cells of titanium modified by sequential immobilization of poly (ethylene glycol) and heparin. J. Mater. Chem. B 2014, 2, 892-902. [CrossRef]

40. Krijgsman, B.; Seifalian, A.M.; Salacinski, H.J.; Tai, N.R.; Punshon, G.; Fuller, B.J.; Hamilton, G. An assessment of covalent grafting of RGD peptides to the surface of a compliant poly(carbonate-urea)urethane vascular conduit versus conventional biological coatings: Its role in enhancing cellular retention. Tissue Eng. 2002, 8, 673-680. [CrossRef] [PubMed]

41. Bellis, S.L. Advantages of RGD peptides for directing cell association with biomaterials. Biomaterials 2011, 32, 4205-4210. [CrossRef] [PubMed]

42. Lin, H.B.; García-Echeverría, C.; Asakura, S.; Sun, W.; Mosher, D.F.; Cooper, S.L. Endothelial cell adhesion on polyurethanes containing covalently attached RGD-peptides. Biomaterials 1992, 13, 905-914. [CrossRef]

43. Walluscheck, K.P.; Steinhoff, G.; Kelm, S.; Haverich, A. Improved endothelial cell attachment on ePTFE vascular grafts pretreated with synthetic RGD containing peptides. Eur. J. Vasc. Endovasc. Surg. 1996, 12, 321-330. [CrossRef]

44. Hoesli, C.A.; Garnier, A.; Juneau, P.M.; Chevallier, P.; Duchesne, C.; Laroche, G. A fluorophore-tagged RGD peptide to control endothelial cell adhesion to micropatterned surfaces. Biomaterials 2014, 35, 879-890. [CrossRef] [PubMed]

45. Le Saux, G.; Magenau, A.; Böcking, T.; Gaus, K.; Gooding, J.J. The relative importance of topography and rgd ligand density for endothelial cell adhesion. PLoS One 2011, 6, e21869. [CrossRef] [PubMed]

46. Dudash, L.A.; Kligman, F.; Sarett, S.M.; Kottke-Marchant, K.; Marchant, R.E. Endothelial cell attachment and shear response on biomimetic polymer-coated vascular grafts. J. Biomed. Mater. Res. A 2012, 100, 2204-2210. [CrossRef] [PubMed]

47. Rémy, M.; Bareille, R.; Rerat, V.; Bourget, C.; Marchand-Brynaert, J.; Bordenave, L. Polyethylene terephthalate membrane grafted with peptidomimetics: Endothelial cell compatibility and retention under shear stress. J. Biomater. Sci. Polym. Edit. 2013, 24, 269-286. [CrossRef] [PubMed]

48. Wang, X.; Cooper, S. Adhesion of endothelial cells and endothelial progenitor cells on peptide-linked polymers in shear flow. Tissue Eng. Part A 2013, 19, 1113-1121. [CrossRef] [PubMed]

49. Inoue, O.; Suzuki-Inoue, K.; McCarty, O.J.; Moroi, M.; Ruggeri, Z.M.; Kunicki, T.J.; Ozaki, Y.; Watson, S.P. Laminin stimulates spreading of platelets through integrin alpha(6)beta(1)-dependent activation of GPVI. Blood 2006, 107, 1405-1412. [CrossRef] [PubMed]

50. Inoue, O.; Suzuki-Inoue, K.; Ozaki, Y. Redundant mechanism of platelet adhesion to laminin and collagen under flow-involvement of von willebrand factor and glycoprotein Ib-IX-V. J. Biol. Chem. 2008, 283, 16279-16282. [CrossRef] [PubMed] 
51. McCarty, O.J.; Zhao, Y.; Andrew, N.; Machesky, L.M.; Staunton, D.; Frampton, J.; Watson, S.P. Evaluation of the role of platelet integrins in fibronectin-dependent spreading and adhesion. J. Thromb. Haemost. 2004, 2, 1823-1833. [CrossRef] [PubMed]

52. Sánchez-Cortés, J.; Mrksich, M. The platelet integrin $\alpha \operatorname{Ilb} \beta 3$ binds to the RGD and AGD motifs in fibrinogen. Chem. Biol. 2009, 16, 990-1000. [CrossRef] [PubMed]

53. Zheng, W.; Wang, Z.; Song, L.; Zhao, Q.; Zhang, J.; Li, D.; Wang, S.; Han, J.; Zheng, X.L.; Yang, Z.; et al. Endothelialization and patency of RGD-functionalized vascular grafts in a rabbit carotid artery model. Biomaterials 2012, 33, 2880-2891. [CrossRef] [PubMed]

54. Corum, L.E.; Hlady, V. Screening platelet-surface interactions using negative surface charge gradients. Biomaterials 2010, 31, 3148-3155. [CrossRef] [PubMed]

55. Yan, B.; Smith, J.W. A redox site involved in integrin activation. J. Biol. Chem. 2000, 275, 39964-39972. [CrossRef] [PubMed]

56. Choi, H.; Aboulfatova, K.; Pownall, H.J.; Cook, R.; Dong, J.F. Shear-induced disulfide bond formation regulates adhesion activity of von willebrand factor. J. Biol. Chem. 2007, 282, 35604-35611. [CrossRef] [PubMed]

57. Engelhardt, S.; Hu, Y.; Seiler, N.; Riester, D.; Meyer, W.; Krüger, H.; Wehner, M.; Bremus-Köbberling, E.; Gillner, A. 3D-microfabrication of polymer-protein hybrid structures with a q-switched microlaser. J. Laser Micro/Nanoeng. 2011, 6, 54-58. [CrossRef]

58. Jacobs, P.F. Rapid Prototyping \& Manufacturing: Fundamentals of Stereolithography; Society Manufacturing Engineering: Dearborn, MI, USA, 1992.

59. Vercruysse, K.P.; Marecak, D.M.; Marecek, J.F.; Prestwich, G.D. Synthesis and in vitro degradation of new polyvalent hydrazide cross-linked hydrogels of hyaluronic acid. Bioconjug Chem. 1997, 8, 686-694. [CrossRef] [PubMed]

60. Shu, X.Z.; Liu, Y.; Luo, Y.; Roberts, M.C.; Prestwich, G.D. Disulfide cross-linked hyaluronan hydrogels. Biomacromolecules 2002, 3, 1304-1311. [CrossRef] [PubMed]

61. Kirihara, M.; Asai, Y.; Ogawa, S.; Noguchi, T.; Hatanov, A.; Hirai, Y. A mild and environmentally benign oxidation of thiols to disulfides. Synthesis 2004, 2007, 3286-3289. [CrossRef]

62. Motlagh, D.; Allen, J.; Hoshi, R.; Yang, J.; Lui, K.; Ameer, G. Hemocompatibility evaluation of poly(diol citrate) in vitro for vascular tissue engineering. J. Biomed. Mater. Res. A 2007, 82, 907-916. [CrossRef] [PubMed]

63. Williams, R.H.; Nollert, M.U. Platelet-derived NO slows thrombus growth on a collagen type III surface. Thromb. J. 2004, 2, 1-11. [CrossRef] [PubMed]

(C) 2016 by the authors; licensee MDPI, Basel, Switzerland. This article is an open access article distributed under the terms and conditions of the Creative Commons Attribution (CC-BY) license (http://creativecommons.org/licenses/by/4.0/). 